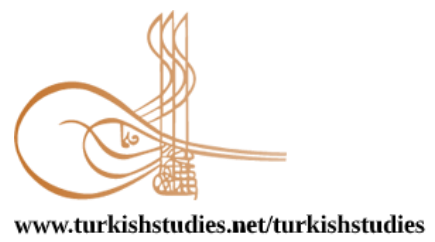

www.turkishstudies.net/turkishstudies
Turkish Studies

eISSN: $1308-2140$

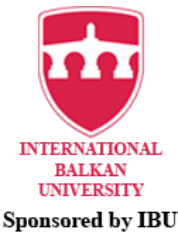

Research Article / Araștırma Makalesi

\title{
Bir Salgın Hastalık Olarak Covid-19'un Gazi Üniversitesi Gazi Eğitim Fakültesi Güzel Sanatlar Bölümü Resim Ana Sanat Dalındaki Öğrencilerin Resimlerine Yansımaları
}

\author{
Reflections of Covid-19 as a Pandemic in the Paintings of the Students at Gazi University Gazi \\ Education Faculty Fine Arts Department Art Painting Major
}

Gonca Yayan*

\begin{abstract}
Along with the decrease of death related with illnesses and improvement on the longevity of life due to developments on the modern medicine from the end of 19th century to present day, chronic illnesses that are seen commonly on societies became important issues. When causal role of social factors on health and disease facts bring fast paced public changes on social, political, economic and cultural fields it effected art and the artist in different levels and reflected in the artworks. Based on social factors, these changes have sometimes led artists to form discourse by first questioning themselves and later their audience along with the events in the society and sometimes led them to form differences by getting out of this circle. Human who can transform the expression of feelings and thoughts such as imagination, longing anxiety through art into a form has also created a system of indicators. These indicators that are necessary for a communication to exist in social factors; signs, symbols, sounds, body movements, etc. are the basic elements of artistic expression. In this context, it is an important requirement for art to be used as an educational tool in order to raise healthy generations, as well as considering the reactions against the events in societies as a communication tool. While there are important health problems in our country, the number of social and cultural studies outside the field of health is also not sufficient. This has been decisive in the identification of this study on Covid-19, and especially in the shortcomings in the field of art. In the study, "literature review" and "work analysis" were chosen as methods. Based on the example of Covid-19, the knowledge, attitudes and behaviors of 13 students from the 3rd and 4th grades in Gazi University Gazi Faculty of Education Fine Arts Department Art Painting Major were questioned with their own perspective and the relationships between these factors and the effects of the disease on them were tried to be analyzed. The findings in the study, which aims to determine how the disease phenomenon affects students with the social and cultural variables mentioned under the name of social factors, were limited to the selected sample and research area. The written permission for the use of the works in the study has been obtained from the owners.
\end{abstract}

Structured Abstract: Human as a biological being has always been under the effect of psychological, environmental and social factors during the period of becoming a community. While these factors may affect people good or bad in different degrees in the event of epidemic throughout their lives, they caused diseases directly

\footnotetext{
*Dr. Öğr. Üyesi, Gazi Üniversitesi, Gazi Eğitim Fakültesi, Güzel Sanatlar Bölümü

Asst. Prof. Dr. Gazi University, Gazi Faculty of Education, Department of Fine Arts Education

ORCID 0000-0002-2915-3137

yayangonca@gmail.com

Cite as/ Atıf: Yayan, G. (2020). Bir salgın hastalık olarak Covid-19’un Gazi Üniversitesi Gazi Eğitim Fakültesi Güzel Sanatlar Bölümü Resim Ana Sanat Dalındaki öğrencilerin resimlerine yansımaları. Turkish Studies, 15(4), 1297-1313. https://dx.doi.org/10.7827/TurkishStudies.44494

Received/Geliş: 24 June/Haziran 2020

Accepted/Kabul: 10 August/Ağustos 2020

Copyright (C) MDE, Turkey

Checked by plagiarism software

Published/Yayın: 30 August/ Ağustos 2020

CC BY-NC 4.0
} 
in societies and changed the course of these diseases. On the other hand, those factors became significantly determinative on perspectives of health and disease and on public lives of individuals.

In those periods, while the pressure on people increases, they experienced difficulties to express themselves. This brought on the association of communication and art as a result of many incidents to become speakable and visible while providing manifestation of many emotions and thoughts that people cannot express.

When looked thorough the history, it is known that the oldest communication tool appeared with the art of painting. While thinking is an important feature of human beings, being able to express and convey thoughts correctly arises as a result of its relations with art, education and culture. And art, as one of the tools of expression, is a feature that belongs to artists.

Therefore, in every society they lived, people, as an expression of their own emotions and thoughts, preferred to reflect their internal and external realities they faced and the incidents they cannot cope with such as pandemic via their artworks.

The phenomenon of death in the losses that occur as a result of epidemic diseases has inspired everything in our daily lives, from rituals to birth, to our way of life, from economy to love, respect and art.

In fact, after many traumatic events from ancient times to today such as epidemics, when humanity faced with death, which had no cure, it was both very scared and helpless, and tried to express its emotions in some way.

The depiction of death which initiated with Humbaba, a monstrous giant protecting cedar forests in Ancient Mesopotamia Religion, and many traumatic events were handled by ancient period artists and shed light on the following periods. history.

In this way, artists brought together the cold face of death in their artworks in different periods of the

From this point of view, on records of history, artists have always covered the psychological effects of societies such as war, genocide, natural disaster, epidemic diseases, childhood traumas and death. Among those there are many artists such as Guy Marchan, Hans Holbein, Johann Elias Ridinger, Rene Magritte, Peter Brueghel, Picasso, Edvard Munch, Gustav Klimt, William Turner and Otto Dix.

For instance, while Peter Brueghel depicted tragedy of plague in his artwork named "Victory of Death" in 1562, Picasso tried to cover the faces deformed by the 3rd degree syphilis disease he saw on the streets of Paris as a result of syphilis contamination in his painting titled "Girls with Avignon" in 1907.

When Rene Magritte was 14 years old, her depressed mother committed suicide. Her mother's body was found dead on the edge of the river with her face covered like a veil. The artist also showed this image of his mother traumatically in his book "Collective Invention". While Gustav Klimt used the Spanish flu, which surrounded the world in 1911, and even killed Klimt, in his work "Death and Life", the artwork made by William Turner in 1840 named "Ship of Slaves" in which black people (300 slaves) died from hunger and disease and thrown to sea on a British slave ship returning from Africa also brought his end.

Otto Dix, who participated in the World War I and II, was injured many times and made his paintings based on these testimonies, included the cold face of war and death in many of his works as an artist. He tried to express that war destroyed both life and death by pulling over the line between them.

The traumas occurring in every period with these paintings and the like have been handled by many artists as an attack against the ruin of life, diseases, ugliness and brutality.

Today, while these epidemics play a determining role on individuals' lifestyles with different traumas, they also have different symptoms on societies. 
In addition to the disease models that changed in parallel with the developments in medicine, it was understood that the epidemic disease had a close relationship with the societies due to the differentiation of epidemic diseases and deaths according to the societies.

When the epidemic diseases (plague, chickenpox, cholera, Spanish flu, AIDS, Covid-19, etc.) included in these traumas along with their metaphorical connotations in societies from ancient times to today are examined, it has seen to have many results.

Today, the problems of this interaction continue to be seen at different levels in all societies, whether developed or underdeveloped.

In these days, the whole world is trying to cope with this epidemic, known as Covid-19, which first appeared in the Wuhan Province of China with respiratory symptoms (fever, cough, shortness of breath). It has seen in many countries like the U.K., Italy, Brazil, Russia, Turkey and especially in the U.S.

The whole world is still at great risk, as the vaccine of the disease is not yet available. Every country takes a series of measures including curfew implementation and continues to protect its citizens from the disease.

In this study, the cultural and social effects of Covid-19, as well as its effects on the society on their knowledge, attitudes and behaviors were analyzed based on the paintings of undergraduate students.

Within the scope of the research, Covid-19, which is the epidemic of today, has been evaluated through the eyes of young people and its reflections on Turkish society has been tried to be explained with 15 different paintings.

Keywords: Pandemic, fear of death, Covid-19, reflections to art

Öz: 19. yüzyılın sonlarından günümüze kadar modern tıp alanındaki gelişmelere bağlı olarak hastalıklardaki ölümlerin azalması ve ortalama yaşam süresinin artması yanında toplumlarda sıklıkla görülen kronik hastalıklar da insanlar için önemli sorunlar haline gelmiştir. Toplumsal faktörlerin sağlık ve hastalık üzerindeki nedensel rolü sosyal, politik, ekonomik ve kültürel alanda hızlı toplumsal değişimleri de beraberinde getirirken sanatı ve sanatçıları farklı düzeylerde etkilemiş, eserlerine de bir şekilde yansımıştır. Toplumsal faktörlerden hareketle bu değişimler sanatçıları yaptıkları her eserde, öncelikle kendilerini sonrasında da izleyicilerini toplumdaki olaylarla birlikte sorgulayarak çeşitli söylemler oluşturmaya bazen de bu döngünün dışına çıkarak farklılıklar yaratmaya yönlendirmiştir. Sanat aracılığıyla, hayal, özlem endişe gibi duygu ve düşüncelerin dışavurumunu bir forma dönüştürebilen insan bu yolla bir göstergeler dizgesi de oluşturmuştur. Toplumsal faktörlerde bir iletişimin var olabilmesi için gerekli olan bu göstergeler; işaretler, semboller, sesler, beden hareketleri gibi sanatsal ifadenin temel elemanlarıdır. Bu bağlamda, sanatın toplumlarda yaşanan olaylar karşısındaki tepkileri bir iletişim aracı olarak ele alması yanında sağlıklı nesiller yetiştirilmesinde eğitim amaçlı olarak da kullanılması önemli bir gerekliliktir. Ülkemizde önemli sağlık sorunları yaşanırken, sağlık alanının dışında sosyal ve kültürel anlamda yapılan çalışmaların sayıları da yeterli değildir. Bu durum, Covid-19 ile ilgili yapılan bu çalışmanın belirlenmesi aşamasında ve özellikle de sanat alanındaki eksikliklerde belirleyici olmuştur. Araştırmada "literatür tarama" ve “eser analizi” yöntem olarak seçilmiştir. Covid-19 örneğinden hareketle, Gazi Üniversitesi Gazi Eğitim Fakültesi Güzel Sanatlar Bölümü Resim Ana Bilim Dalı'ndaki 3. ve 4.sınıf öğrencilerinden 13'ünün eserleri sosyal ve kültürel açıdan Covid-19 olgusuna ilişkin bilgi, tutum ve davranışları kendi bakış açıları ile sorgulanmış; ayrıca bu faktörlerin birbirleriyle ilişkileri ve hastalığın üzerlerindeki etkileri analiz edilmeye çalışılmıştır. Toplumsal faktörler adı altında ele alınan söz konusu sosyal ve kültürel değişkenlerle hastalık olgusunun öğrencileri ne şekilde etkilediğini tespit etmeyi amaçlayan çalışmadaki bulgular, seçilen örnekler ve araştırma alanı ile sınırlı tutulmuştur. Makaledeki eserlerin kullanımı için sahiplerinden yazılı izin alınmıştır.

Anahtar Kelimeler: Salgın hastalıklar, ölüm korkusu, Covid-19, sanata yansımaları 


\section{Giriş}

Günümüzde sağlık ve hastalık her ne kadar sadece tıbbın konusu gibi görünse de sosyal bilimlerin incelediği konular arasında da yer almaktadır. Bu durum sağlık ve hastalığın sadece biyolojik süreçlerle açıklanabilecek olgular olmaması ve sosyal yapılar içinde oluşurken bütün sağlık sistemlerini de kendi tarihsel süreçleri ve toplumsal koşullar bağlamında da etkilemesinden kaynaklanmaktadır. Bu açıdan bakıldığında, sağlık ve hastalık kavramlarının toplumsal faktörlerden ayrı düşünülüp değerlendirilmesi de mümkün değildir. Çünkü toplumsal faktörler, bireylerin yaşam tarzları üzerinde belirleyici rol oynarken farklı hastalık örüntülerine neden olabildiği gibi; sağlık ve hastalığın tanımlanışı, rahatsızlığ1 algılama ve değerlendirme, hastalığa gösterilen tepkiler, geleneksel ve popüler tedavi tercihleri gibi pek çok davranış üzerinde de doğrudan ya da dolaylı olarak pek çok etkiye de sahiptir (Tekin, 2007: 1).Toplumsal faktörlerin sağlık ve hastalık olguları üzerindeki nedensel rolü, etkileme sınırları ve dereceleri her zaman açı olmamakla birlikte, günümüzde bu faktörler ile sağlık ve hastalık olguları arasında karşılıklı bir etkileşimin olduğu öngörülmektedir. İster gelişmiş ister geri kalmış toplumlar olsun her toplumda bu etkileşime ait sorunlar farklı düzeylerde görülmektedir (Tekin, 2007: 2).

Bu araştırmada, Gazi Üniversitesi (G.Ü.) Gazi Eğitim Fakültesi Resim Ana Bilim Dalı'ndaki öğrencilerin sosyal ve kültürel açıdan Covid-19'a ilișkin bilgi, tutum ve davranıșlardan ne șekilde etkilendikleri ve resmettikleri eserlerden yola çıkılarak toplumda Covid-19 olgusunun yarattığg etkilerin aktarılması amaçlanmıştır.

Sağlık ve hastalık, günümüzde birbirinden tamamen ayrı kavramlar olmayıp örtüşen kavramlar olarak karşımıza çıkmaktadır (Baltaş, 2000: 34). Fakat sağlık ve hastalık kavramları, her kültürde farklı algılanan kavramlardır. Yani bir toplumdaki hastalık algısı ile başka bir toplumdaki hastalık algısının aynı olması mümkün değildir. Dolayısıyla bir toplumun hastalık hakkındaki değer yargıları, hastalığa bakış açısı ve seçilen tedavi şekilleri; o toplumun kültürünün özelliklerini yansıtmaktadır. Bu yönüyle kültürler arasındaki farklılıklar göz önüne alındığında sağlık ve hastalık kavramları ile çevrelerinde yer alan pek çok kavram da aynı derecede göreceli olup kültürden kültüre farklılıklar gösterecektir (Kaplan, 2016:13).

Günümüzden tarihsel süreçlere doğru bakıldığında, hastalık kavramının yanı sıra hastalık nedenlerinin ve hastalığa özgü tedavi yollarının da önemli ölçüde değişiklik geçirdiği görülmektedir. "Hastalık" (disease), kültürel veya psikolojik olarak kabul edilmiş olan ya da olmayan bir organizmanın patolojik hali olarak tanımlanmaktadır. "Sağlıksızlık" (sickness) yani sağlıktaki bozulma ise sağlıksız olma hali, rahatsızlık ve hastalık olgularını da içeren, daha geniş kapsamlı bir terim olarak literatürde yer bulmaktadır. Rahatsızlık (illness) terimi ile ise, sağlıksız olma halinin, kültürel ve sosyal olarak tanımlanmış ve koşullandırılmış deneyimlere ilişkin yönü işaret edilmektedir (Helman, 1984)

Tarihin ilk dönemlerinde tarım öncesi avcılık ve toplayıcılıkla uğraşan toplumlarda insanlar, hayatlarını hastalıklardan ziyade genellikle çevresel nedenlerle ve daha çok da av kazaları sonucu kaybetmişlerdir. Tarım toplumlarda durum değişmiş hava, su, yiyecek ve vektörlerle bulaşan enfeksiyon hastalıkları yaygınlaşmış ve bu salgın hastalıklar da çok sayıda insanın ölümüne de yol açmıştır (Tekin, 2007: 28). Bugün ise modern toplumlarda enfeksiyon hastalıklarının yerini kronik hastalıklar alırken; salgın hastalıklar, kanser ve kalp rahatsızlıkları ölüm nedenlerinin başında yer almaya da başlamıştır (Fitzpatrick, 1991: 4-5). Çağdaş dönüşümlerle de çeşitli kavramlar, örneğin hastalık yerine sağl1k hastane yerine topluluk içinde bakım, tedavi yerine koruma, müdahale yerine gözetim ve hasta yerine kişi gibi tanımlarla yer değiştirmiştir (Nettleton, 1995: 12) Hatta bu toplumsal faktörler içinde özellikle salgın 
hastalık, bireylerin yaşam tarzları üzerinde belirleyici bir rol oynarken toplumlar üzerinde de farklı belirtilere neden olabilmiş; sağlık ve hastalığın tanımları ile rahatsızlığı algılama ve değerlendirme, hastalığa gösterilen tepkiler, tıbbi yardım aramaya karar verme, sağlık hizmetlerinden yararlanma, geleneksel ve popüler tedavi tercihleri gibi pek çok davranış sonucunda ya doğrudan ya da dolaylı olarak herkesi etkilemiştir (Tekin, 2007: 1).

Bütün dünyanın etkilendiği ve devletleri kasıp kavuran, şu ana kadar da ilacı bulunamamış olan koronavirüs (Covid-19) hastalığı insandan insana damlacık yoluyla bulaşmakta olup hastalığın kaynağının ise Çin'in Hubei eyaletinin Wuhan şehrinde Huanan Deniz Ürünleri Toptan Satış Pazarı'nda yasadışı olarak satılan vahşi hayvanlar olduğu düşünülmektedir. 31 Aralık 2019'da DSÖ Çin Ülke Ofisi, kaynağ1 henüz netlik kazanmamış ve nedeni bilinmeyen koronavirüs olarak tanımlanan bu salgın hastalığın 7 Ocak 2020'de daha önce insanlarda tespit edilmemiş yeni bir tür koronavirüs olduğunu tanımlarken kökeninin de hala araştırıldığını belirtmiştir (S.B. Sağlık Çalışanları Rehberi, 2020: 3-4).

Dünya, Covid-19'un meydana getirdiği sağlığa ve toplumlara yönelik problemleri çözmeye çalışmaktadır. Bu tür dönemlerde insanların üzerindeki baskılar yoğunlaşmakta ve insanlar kendilerini ifade etmekte zorlanmaktadırlar. Bu durum, toplumlarda insanların ifade edemedikleri pek çok duygu ve düşüncelerinin sanat yoluyla dışa vurulması sonucunu ortaya çıkarmış ve pek çok olayın konuşulabilir ve görülebilir hale gelmesini sağlayarak sanatla iletişimin birlikteliğini gündeme getirmiştir. Çünkü sanat, yaşamın bir temsili olarak sanatçının veya bireyin hayatını nasıl yorumladığı ya da kendisini nasıl tanımladığının bir ifadesidir. Bu yönüyle de her dönemde ve her toplumda karşımıza çıkan bir olgu olarak insanların duygu ve düşüncelerini dile getirdikleri, kendilerini ifade ettikleri bir yol olmuştur. Sanatçılar yaptıkları her eserle, kendilerinin ve toplumlarının kimlik göstergelerini sunmuşlardır. Kısaca, sanat, hayatın gerçek öznelerini göstermeye yardımcı olmaktadır.

Sanat; aynı zamanda insana, topluma ve toplumsal hayata sıkı bir şekilde bağlıyken öz ve biçim olarak ulusal, evrensel, soyut, somut, duyusal ve düşüncelerle birbirinden asla ayrılamaz bir bütündür. (Hançerlioğlu, 1982: 364)

$\mathrm{Bu}$ anlamda tarihte toplumlarda yaşanan türlü travmalar öncesi ve sonrasında sanatçılar derinden etkilenmişler ve ortaya çıkardıkları eserler ile toplumların dikkatini çekmişlerdir.

Foster'a göre toplumlardaki çeşitli travmalardan etkilenen her bireyin bu travmalar sonrasında gözlemlenen stres bozuklukları gibi olayları incelendiğinde; bilim sadece, travmayı yaşayanların kim olduğuyla ilgilenmezken popüler kültürde hem travmada durum, neden, sonuç ilişkileri hem de öznesi olayın konumuyla ilgilendirilmiştir (Foster, 2009: 209). Bu travmaların sanat alanında görünür hale gelmesiyle de sanatçıların ruhsal durumu ile kurulan bağ da sanat eserinin daha net anlaşılması ve yorumlanmasına imkân sağlanmıştır (Aslan, 2019: 59). Böylece sanat bazen hayatın zorluklarından bazen hatırlanmak istenmeyen gerçeklerden bazen de beklenmeyen gelecekten kaçışı sağlamıştır (Ayaydin, 2020: 10).

$\mathrm{Bu}$ açıdan bakıldığında tarihin sayfalarında sanatçılar, toplumların psikolojik olarak etkilendikleri savaş, soykırım, doğal afet, salgın hastalıklar ve çocukluk çağında yaşanılan, travma ve ölüm gibi olguları bir şekilde eserlerinde hep işlemiş̧lerdir (Soygür, 1991: 127).

Bu travmalar içinde yer alan salgın hastalıkların (veba, su çiçeği, kolera, İspanyol gribi, AIDS, Covid-19 gibi), Antik Çağ'dan günümüze kadar olan toplumlardaki metaforik çağrışımları irdelendiğinde pek çok olumsuz sonuçlarının olduğu gözlemlenmiştir. Örneğin Orta Çağ'da, tek Tanrılı inançların benimsenmesiyle, bu hastalıklar, Allah'ın bir gazabı olarak görülmüş ve cezadan sorumlu bir 
günah keçisi arayışını da daima beraberinde getirmiştir. Aynı zamanda, tarihin en eski dönemlerinden beri salgın hastalıkların var olması ile meydana gelen farklı oluşumlar da tarihin akışını yeniden şekillendirmiştir (Sarıbaş, 2019: 2471).

Örneğin; Orta Çağ'da frengi ve veba, 19. yüzyılda tüberküloz, 20. yüzyılda kanser ve AIDS gibi hastalıklarla mücadele eden toplumlar için, "kötülükle" özdeşleştirmek istedikleri "kurbanlar" da tarihin her döneminde varlığını koruyan bu hastalıklarla "ilahi gazabın" bir aracı olarak görülmüştür (Sontag, 2015: 51). Dolayısıyla, eski çağlardan günümüze kadar dünya coğrafyasında yaşanan veba ve benzeri salgınlara bağlı felaketler sonucunda insanlar hep çaresiz kalmış ve yaşanan toplumsal histerinin sonucu olarak toplumların farklı kesimlerindeki "ortak kaygıları" beraberinde getirmiştir (Sarıbaş, 2019: 2472)

Toplumsal faktörlerin sağlı ve hastalık olguları üzerindeki söz konusu nedensel rolü, etkileme sınırları ve dereceleri her zaman açı olmamakla birlikte, günümüzde bu faktörler ile sağlık ve hastalık olguları arasında karşılıklı bir etkileşim söz konusudur. Bugün ister gelişmiş ister geri kalmış bir toplum olsun, bütün toplumlarda bu etkileşime ait sorunlar farklı düzeylerde görülmeye devam etmektedir (Tekin, 2007:2).

Aslında tarihte ve günümüzde toplumsal faktörlerin içinde ölüm, en çok korkulan ve insanların en aciz olduğu olgulardan biri olarak gözlemlenmektedir. Ölüm olgusu, günlük yaşantıdaki ritüellerden, doğuma ve yaşam şekline; ekonomiden, aşka, saygıya ve sanata kadar her şeyin başlangıcı ve yürütücüsü konumunda olmuştur (Anter, 2018: 5)

Tarihte ilk olarak ölümle ilişkilendirilen Humbaba veya Huwawa da (M.Ö.2000), öldürüldüğünde yüzü maskeye dönüştürülerek ifadesi yok edilmiş ve ölümün soğuk yüzü bu şekilde o dönemin sanatçıları tarafından ilk defa tarih sahnelerindeki yerini almıştır (Resim 1-2). Tarihin sayfalarında ölümle ilişkilendirilen bu ve bunun gibi pek çok travmatik olay, dönem sanatçıları tarafından ele alınarak o dönemlere ışık tutmuştur (Levinas, 2014:16).

Resim-1: Humbaba Maskesi, M.Ö 1800-1600, British Müzesi İngiltere

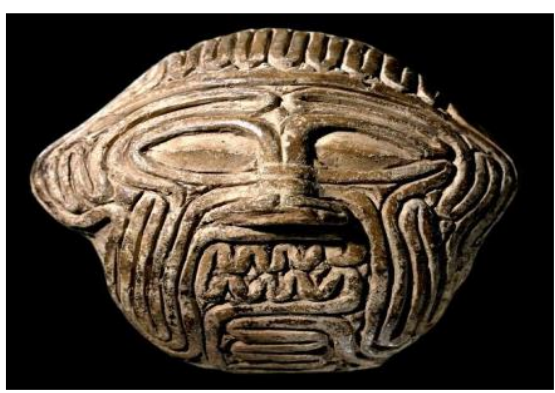

Resim-2: G1lgamış ve Enkidu'nun Humbaba'yı Öldürdügü Rölyef,

M.Ö 2.000, Vorderasiatisches Müzesi Almanya

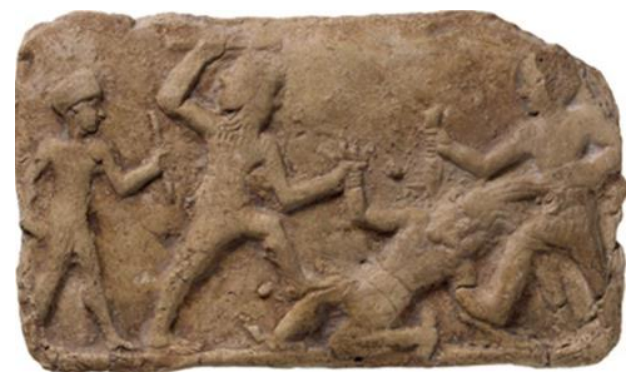

Ölüm, bütün canlılar için nerede, nasıl ve ne zaman yaşanacağı bilinmeyen kesin sondur. Bu sebeple insanlar, hayatlarında yaşayacakları tek ortak nokta olan ölümü kendini var etme savaşında kültürlerine yansıtmışlardır. Ölüm, insanların üzerinde çok konuştuğu, düşündüğü ve çeşitli eserler 
yarattığı alanlardan biri olsa da hakkında en az şey bilindiği ve belki de hiçbir zaman çözülemeyeceği en büyük sır olarak kalacaktır (Anter, 2018: 3).

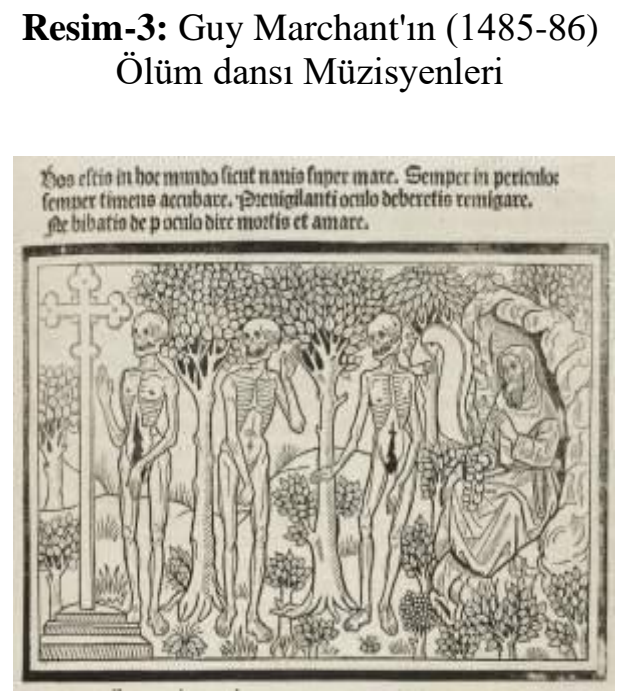

\section{Resim-4: Hans Holbein, 1538}

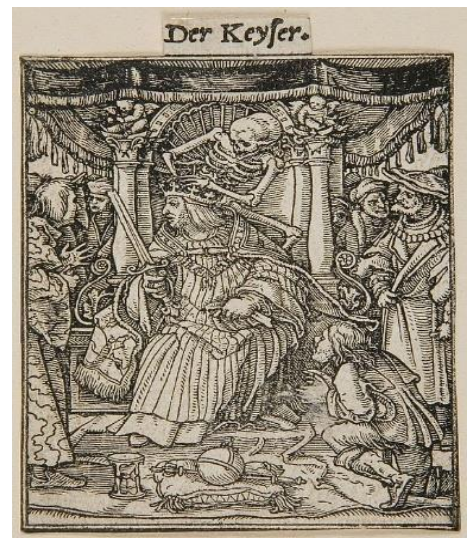

Resim-5: Johann Elias Ridinger Ölüm dansı betimlemesi 18.yy

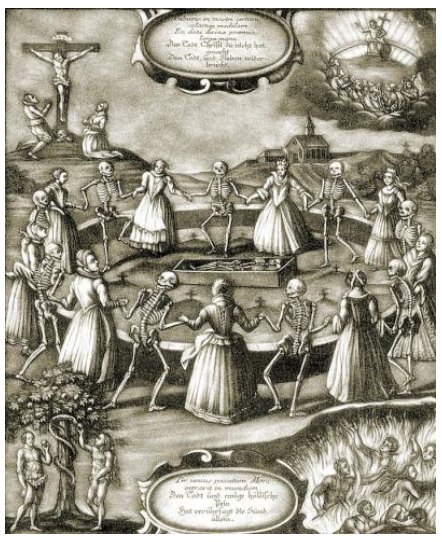

$\mathrm{Bu}$ düşünceden hareketle tarihin farklı dönemlerinde sanatçılar, eserlerinde ölümün soğuk yüzünü insanlarla buluşturmuşlardır. Örneğin; 1485-86 tarihli Guy Marchant'ın ölüm dans1 (müzisyenler) betimlemesinde ölüm, çürümüş insan iskeletleri halinde, çeşitli sinıf insanlarla (kral, şövalye, tüccar, doktor, hırsız, köylü, din adamı) çalgılar eşliğinde dans etmektedir. Burada amaç; hangi sınıftan olunursa olunsun ölümün daima insanın yanı başında olduğunun hatırlatıp, acının gerçek yüzünün gösterilmesi olmuştur (Resim- 3) (http://www.dodedans.com/Eparis-1486.htm, 2020).

Tarihte ölüm dansı betimlemelerini ahşap gravür şeklinde 1538 yılında tamamlayan Hans Holbein de ahşap gravür serisinde tam 41 parça ölüm dansı betimlemesi yapmış ve bu çalışmalarından en ilginç olanı da imparatorun tahta oturduğu anda bile ölümün ensesinde olabileceğini gösteren çalışması olmuştur (Resim-4) (https://www.nybooks.com/daily/2017/01/20/even-the-emperor-holbeindance-of-death/, 2020).

On sekizinci yüzyıl ortalarında ise Johann Elias Ridinger da farklı bir ölüm dansı betimlemesi çizmiştir. Bu betimlemesinde, bir mezarlığın etrafında imparatordan çocuğa kadar değişik sınıflardaki insanların ölüm ile kol kola dans ettiği görülmektedir (Resim-5) (https://www.tumblr.com/search/johann\%20elias\%20ridinger, 2020).

On dokuzuncu yüzyıl sonları ve yirminci yüzyıl başlarında yapılan araştırmalardan da tanınmış yazarlar ve ressamların ölüm karşısındaki çaresizliklerinin onları ruhsal olarak derinden etkilediği ve onların birinci derece akrabalarında da yüksek oranda ruhsal bozukluklar ve intihar eğilimlerinin olduğunu görülmektedir (Soygür, 1999: 128).

Her toplumda insanların duygusal ya da psikolojik olarak uzaklaşmalarının mümkün olmadığı süreçlerde çeşitli travmaların, yaşadıkları fiziksel deneyimler yanında hafizalarında da kendi kendini tekrarlama sürecine girdiği gözlemlenmiştir (Schudson, 2007: 184). 
Bahse konu toplumsal travmalardan olan savaş, soykırım, salgın hastalık ve benzeri olayların sonucunda ortaya çıkan söz konusu insani tepkilerin, bir bilinç altında birleştirilerek ortak bir temsile dönüşmesi beklense de yaşanılan her kötü anın peşi sıra, bireylerin olayları kendi bakış açıları ile ele aldıkları ve ben merkezci bir dışavurum sergiledikleri de görülmüştür.

Bu bakış açıları yanında, salgın hastalık, soykırım ve benzerleri, yirmi birinci yüzyılın ideolojik söylemleri ile her toplumda, insan bedeni üzerinde yapılan her türlü etnik, dinsel, kültürel değişim ve dönüşümlerle de pek çok metaforu beraberinde getirmiştir (Sarıbaş, 2019: 2470).

$\mathrm{Bu}$ yüzden her ne kadar travmatik durumlar toplumlarda insanlarla birlikte yaşanmış olsa da olayların etkilerinin kişiden kişiye göre de farklılıklar göstermesi çok doğaldır (Aslan, 2019: 63).

İnsanlar hastalık veya ölümlerin ortaya çıkardığı psikolojik travmalarla, iç dünyaları ve dış gerçeklikleri arasında bir uyumsuzluk yaşarken, inkâr ettiklerini değiştiremeseler de daima kendi psikolojik gerçekliklerini değiştirme eğiliminde olmuşlardır (Yüksel, 2016: 46).

Örneğin; 1562`de ressam Peter Brueghel "Ölüm Zaferi” adlı eserinde (Resim-6) vebanın korkunçluğunu gösterirken, 1907'de Picasso da "Avignon'lu Kızlar" adlı tablosunda, frenginin bulaşması sonucu (Resim-7) Paris sokaklarında gördüğü 3. derece frengi hastası olan insanların deforme olan yüzlerini maskelerle kapatarak örtmeye çalışmıştır (Genç, 2011: 188)

$\mathrm{Bu}$ resim ve benzerleri ile her dönemde oluşan travmalar, yaşamın harap olmuşluğuna, hastalıkların, çirkinliğine ve acımasızlığına karşı bir saldırı niteliğinde pek çok sanatçı tarafından ele alınmıştır (Kaftanoğlu, 2009: 193).

Resim-6: Peter Brueghel Ölüm Zaferi 1562 'de, ahşap üzerine yağlı boya 117 x $162 \mathrm{~cm}$ Prado Müzesi Madrid

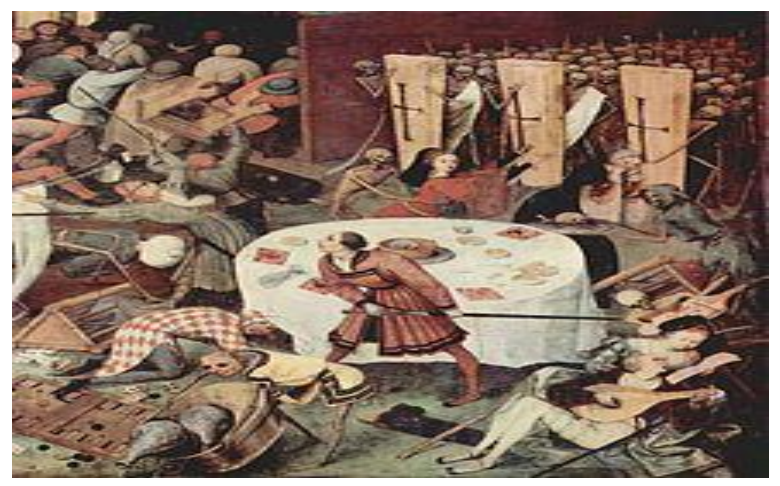

\section{Resim-7: Picasso'nun Avignonlu Kızlar}

1907 tarihli $244 \times 235 \mathrm{~cm}$

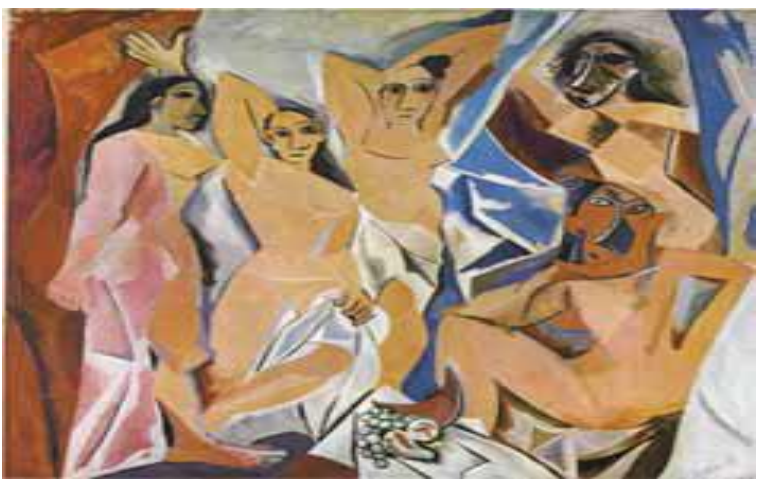

Örneğin, Edvard Munch (1863-1944) 5 yaşındayken annesini, daha sonra da kız kardeşini (o dönemin salgın hastalığı olan) veremden kaybetmiştir (Resim 8-9-10-11). Peş peşe yaşadığı bu kayıplarla baş etme yöntemi olarak eserlerinde, ölüm, yalnızlık, sıkıntı, korku ve depresyon konularını sık sık işlemesi de kaçınılmaz olmuştur (Aslan, 2019: 66-67). Aslında sanatçının bu çalışmalarına kendisinin yaşamı algılayarak içselleştirmesi sonucunda o dönemin gerçeklerini yansıtan eserler olarak da bakmak gerekir (Tepey1lmaz, 2016: 998). 


\begin{tabular}{|c|c|c|c|}
\hline $\begin{array}{l}\text { Resim-8: Edvard Munch, } \\
\text { 1897, Ölü Anne ve Çocuk } \\
\text { /The Dead Motherand the } \\
\text { Child. }\end{array}$ & $\begin{array}{l}\text { Resim-9: } \\
\text { Edvard } \\
\text { Munch,1893, } \\
\text { Çı̆̆lik The } \\
\text { Scream. }\end{array}$ & $\begin{array}{l}\text { Resim-10: Evening on Karl } \\
\text { Johan Street çaresizlik } 1892\end{array}$ & $\begin{array}{c}\text { Resim-11: Edvard } \\
\text { Munch- Golgota } \\
\text { (1900) }\end{array}$ \\
\hline
\end{tabular}

1898-1967 tarihlerinde yaşamış olan Rene Magritte, 14 yaşında iken, depresyonda olan annesi intihar etmiştir (Resim-12). Annesinin cesedi, geceliği peçe gibi yüzünü örtmüş bir şekilde irmağın kenarında ölü bulunmuştur. Sanatçı da annesinin bu görüntüsünü, travmatik olarak "Kollektif Buluş" adlı eserinde göstermiştir (Aslan, 2019: 68). Gustav Klimt 1911 yılında Büyük Savaş ateşi ile dünyayı sarıp sarmalayan ve hatta Klimt'in de ölümüne sebep olan İspanyol gribini "Ölüm ve Yaşam" adlı eserinde kullanırken; (Resim-13) William Turner'ın 1840'ta yaptığ 1 Afrika'dan dönen İngiliz köle gemisinde açlık ve hastalıktan ölerek denize atılan siyahi insanların (300 kölenin) resmedildiği "Kölelerin Gemisi" adlı eseri (Resim-14) sanatçının kariyerinin sonunu da getirmiştir (Aslan, 2019: 69).

\section{Resim-12: Rene Magritte Kollektif Buluş \\ 1934 tuval üzerine yağlıboya. 73.5 x $97.5 \mathrm{~cm}$. Kunstsammlung Nordrhein- Westfalen, Düsseldorf, Almanya.}
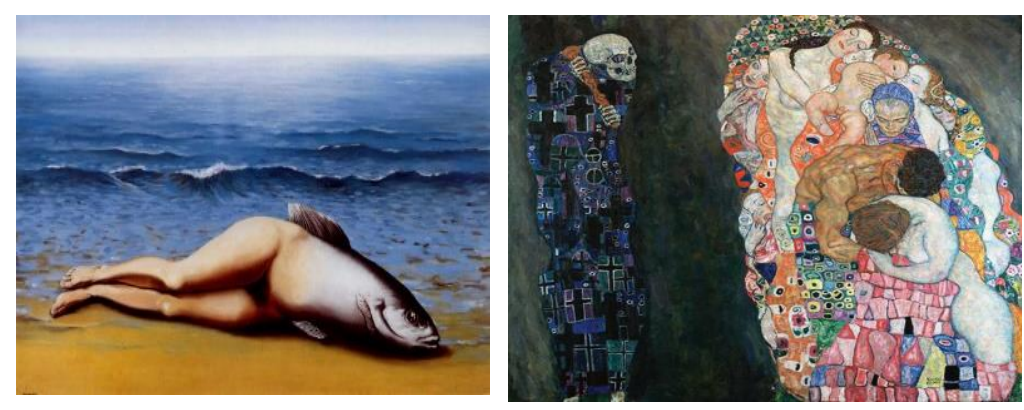
Resim-13: Gustav Klimt, Ölüm ve Yaşam,

178 x $198 \mathrm{~cm}, 1908-1916$, Tuval üzerine yağlıboya, Leopold Müzesi, Avusturya

\section{Resim-14: William Turner, Köle Gemisi,} 90,8x122.6 cm, 1840, Tuval Üzerine Yağlıboya, Güzel Sanatlar Müzesi, Boston, ABD

Yaşanan son aylara bakılacak olunursa, Covid-19 adıyla anılan ve ilk olarak Çin'in Wuhan şehrinde solunum yolu belirtileri ile (ateş, öksürük, nefes darlığı) ortaya çıkan salgın hastalıkla bütün 
dünya baş etmeye çalışmaktadır. Başta Amerika olmak üzere İngiltere, İtalya, Brezilya, Rusya, Türkiye gibi pek çok ülkede bu hastalık baş göstermiştir.

İnsanların ve tıp doktorlarının aciz kaldığı söz konusu salgın hastalığın ne zaman sona ereceği de hâlihazırda bilinmemektedir. Bu salgın hastalık, genellikle 60 yaş ve üzerindeki kişileri daha fazla etkilerken en fazla koronavirüs vakasının görüldüğü ülke olan ABD'de, 6,036,180 kişi Covid-19'a yakalanmıştır.

28 Ağustos 2020 tarihli Worldometers verilerine göre şu ana kadar belirlenen toplam vaka sayısı 24,568,547, toplam ölü sayıs1 ise 833,870'dir. Covid-19 nedeniyle insanlar hayatlarını kaybederken, yaklaşık verilerle ABD'de 185 bin, Brezilya'da 110 bin, Meksika'da 62 bin, İngiltere'de 41 bin kişi ve Türkiye'de 6 bin kişi yaşamını yitirmiştir. Dünya genelinde risk büyük ölçüde devam ederken, Amerika ve Brezilya'da her geçen gün tablo daha da kötüleşmektedir (https://www.worldometers.info/coronavirus/, 2020).

Hastalığın aşısı bulunamadığından dolayı bütün dünya hala büyük bir risk altındadır. Dünya genelinde uygulanan başta sokağa çıkma yasağı olmak üzere, çoğu ülke bir dizi önlem alarak vatandaşlarını bu hastalıktan korumaya devam etmektedir.

Ülkeler de Covid-19 nedeniyle kısa süreli ya da uzun süreli olarak ev, okul, fabrika gibi alanları kapsayan birtakım uygulamalar yapma gereğini duymuşlardır. Sadece tek bir kişiyi ilgilendirir gibi görünen bu hastalık, zincirleme olarak dünya genelinde bütün toplumlara büyük zararlar vermeye devam etmektedir (Erefe ve Diğerleri, 1996: 9).

Uzun süreli sokağa çıkma yasağının olduğu dönemde insanlar, evlerinde hapis bir şekilde hayatlarını devam ettirmeye çalışırken pek çok insan işsiz kalmış ve pek çok işyeri de kapanmıştır. Hastaneler koronavirüslü hastalarla dolup taşarken yer bulunamaması nedeniyle bazı ülkelerde sağlıksız şartlarda insanlar ölüme terk edilmiş hatta tabut yetiştirilememesinden dolayı toplu mezarlara gömülmeleri de söz konusu olmuştur. Bunun sonucunda, hastalığın bulaşma özelliği ve ölüme terk edilenlerin yanında imkansızlıklar sebebiyle de açlığa terk edilen insanlar olmuştur.

Aslında biyolojik bir varlık olarak dünyaya gelen her insan, toplumsallaşma süreci içerisinde psikolojik olarak, yaşadığ 1 çevre ve sosyal faktörlerin etkisi altında kalmaktadır. Bu faktörler kişilerin yaşamları boyunca sağlıkta ve hastalıkta farklı derecelerde, iyi veya kötü yönleriyle onları etkileyebilirken toplumsal olarak ta hayatları üzerinde önemli ölçüde belirleyici olabilmektedir.

Toplumsal faktörlerin sağlık ve hastalık olguları üzerindeki nedensel rolü, etkileme sınırları ve dereceleri her zaman net olmamakla birlikte, günümüzde bu faktörler ile sağlık ve hastalık olguları arasında karşılıklı bir etkileşimin olduğu kabul edilmektedir. İster gelişmiş ister geri kalmış olsun, tüm toplumlarda bu etkileşime ait sorunlar farklı düzeylerde görülmeye de devam etmektedir. (Tekin, 2007: 2)

Toplumsal-kültürel farklılıklar içeren bu hastalıklar ister sübjektif ister objektif anlamda olsun, bireysel düzeyde ruhsal, fiziksel; toplumsal düzeyde de uyumsuzluk veya çeşitli dengesizlikleri de beraberinde getirmektedir. $\mathrm{Bu}$ anlamda bir bireyin hasta olarak tanımlanma sürecinde ve çevresindekilerle birlikte değerlendirilmeleri de büyük önem taşımaktadır (Oskay, 1993: 104). Aynı zamanda hastalık bulgularını yorumlama, değerlendirme ve tıbbi yardım arama kararı bireylerin cinsiyeti, yaşı, mesleği, dini, içinde yer aldığı sosyal sınıfı, kültürel yapısı gibi pek çok faktörü de etkilemektedir (Tekin, 2007: 32) 
Bu düşüncelerden yola çıkarak günümüzün salgın hastalığı olan Covid-19, G.Ü. Gazi Eğitim Fakültesi resim öğrencilerinin gözünden değerlendirilmeye çalışılmıştır. Bu hastalığın Türk toplumu üzerindeki yansımaları geleceğin resim öğretmenlerinin penceresinden 15 farklı resimle anlatılırken ortaya aşağıda yer alan resimler ve yorumları çıkmıştır.

Alttaki ilk resim örneğinde iki sağlık çalışanı şırınga ve ilaç tozlarını hasta olan bir kadına uygulamaya çalışmaktadır. Kadın hasta ise bu resimde panik halinde resmedilmiştir. Arka planda yer alan dünya haritasından da anlaşılacağ 1 üzere, hastalık bütün dünyada kol gezmekte olup bütün sağlık çalışanlarını temsilen bu iki sağlık çalışanı ellerinden geleni yapmaktadırlar. Resimde her yer Covid-19 virüsüyle dolu bir şekilde gösterilmiştir. Fakat resmin sol tarafında doğmak üzere olan bir güneş ise sarı renk tonlarıyla bu hastalığın geçeceğine dair ipuçlarını vermektedir (Resim-15).

Ortada yer alan resimde ise bu hastalık süresince gösterdikleri fedakarlıklarından dolayı dünyadaki bütün sağ lık çalışanları adına bir sağlık çalışanı altın bir taçla taçlandırılmıştır. Arka plandaki siyah renkle hala devam eden tehlikenin ciddiyetine vurgu yapılmıştır (Resim-16).

Üçüncü resimde ise ağırlıklı olarak korona günlerinde Sağlık Bakanlığı'nın açıkladığı Türkiye genelindeki günlük hastalık verilerine yer verilmiştir. Resmin orta kısmı ve sol alt kısmında iki sağlık çalışanı maskeli olarak ve yoğun hastalık dönemlerindeki durumuna dikkat çekmek için kan ter içerisinde resmedilmiştir. Ortada yer alan erkek figürü endişeli bir şekilde bakmaktadır. Sol altta yer alan sağlık çalışanlarına da aslında bir saygı duruşu (bütün dünyada sağlık çalışanlarına yaptıkları gayret ve fedakarlıklarından dolayı insanlar alkış tutmuşlardır) söz konusudur. Resmin sol üst köşesinde yer alan "Luppo" adlı gofret haberlerde de yer almıştır (Resim-17). Şöyle ki sokağa çıkma yasağının uygulanacağı bir hafta sonundan önce vatandaşın biri marketten alınacak acil ihtiyaç listesinde bu ürüne de yer vermiştir (!).

Resim-15: Şeyma Sarı 2020

Resim-16: Deniz Özmen 2020

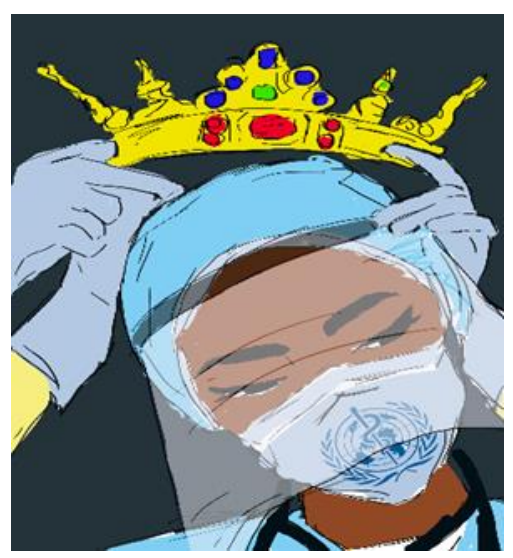

Resim-17: İlkay Yüksel 2020

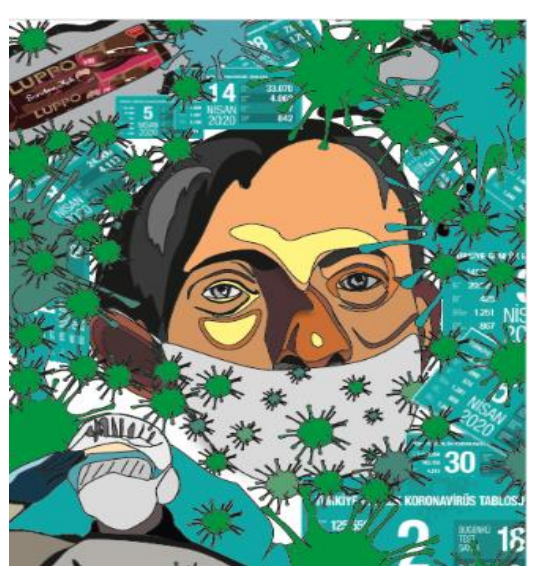

Alttaki diğer resimde siyah olarak resmedilen ve ölümle ilişkilendirilmiş bir insan iskeleti zehirli gaz maskeli olarak gösterilmiş olup kırmızı renkle (Covid-19) tehlikesine dikkat çekilmiştir. Bu figürün altında maskeli bir sağlık çalışanının maskesinde koronavirüs yazısı ile bu hastalıkla sağlık çalışanlarının mücadelesine vurgu yapılmıştır. Resmin sol üst kısmında ise yaşlı bir erkek figürü maskeli ve endişeli bir şekilde gösterilmiş (çünkü hastalık 60 yaş üstünü daha çok etkilemektedir) olup virüsle boğuşmaktadır. Resimde kızıl haçla dünya geneline de bir gönderme yapılmıştır (Resim-18). 
Ortada yer alan resimde ise Covid-19 ile mücadele etmek için dünyanın her yerinde sağlık çalışanlarının emek sarf ettiği ve dünyanın yükünü sırtlandıklandıkları gösterilmeye çalışılmıştır (Resim19).

En sağdaki resimde ise haykırış içerisinde olan bir erkek figürü ile maskelerindeki bayraklardan anlaşılacağı üzere farklı ülkelerdeki insanlar ve sağlık çalışanlarının maskeler içerisindeki hastalıkla mücadelelerine yer verilmiştir (Resim-20).

Resim-18: Hatice Nur İcik 2020

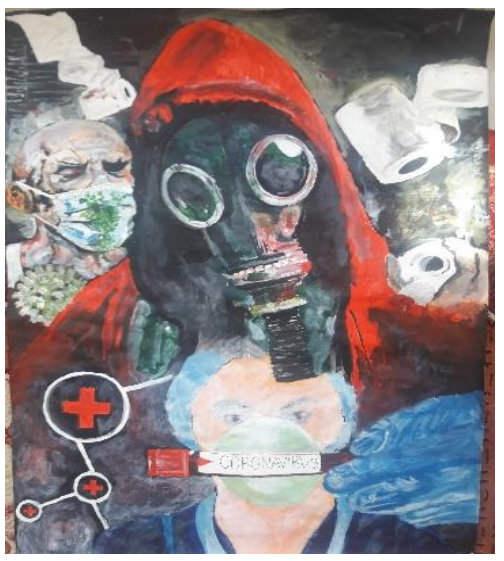

Resim-19: İlkay Yüksel 2020

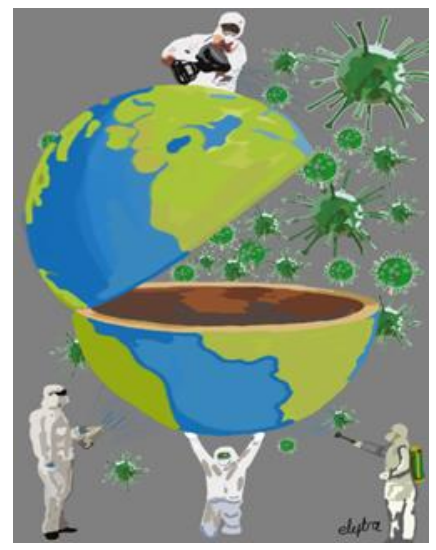

Resim-20: Merve Ateş 2020

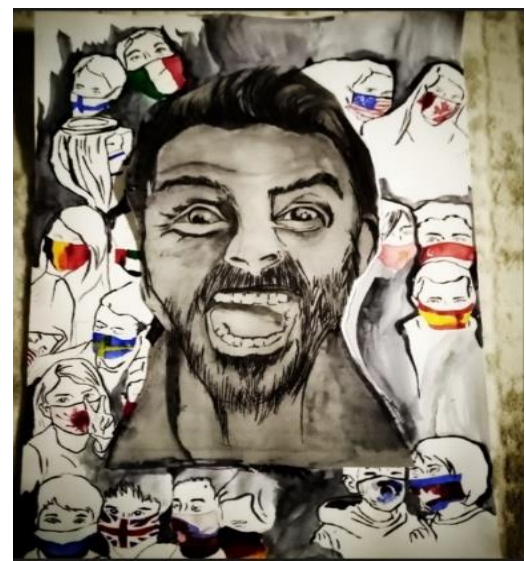

Alttaki diğer resmin sol üst köşesinde ise endişeli ve panik içerisinde yaşlı bir erkek figürü resmedilmiş ve etrafı kırmızı renkte tehlike arz eden korona virüslerle çevrilmiş olup resmin alt tarafındaki kara bulutlarla da tehlikenin devam ettiğine dikkat çekilmiştir (Resim-21).

Ortadaki resimde de etrafı virüslerle çevrili ve haykırış içerisinde orta yaşlarda bir erkek figürüne yer verilmiştir. Figürün altında dünya haritası yer almakta ve kullanılan yeşil ile mavi renklerle de bir kurtulma ümidine bir vurgu yapılmıştır (Resim-22).

En sağdaki resimde ise hastalık döneminde dünya genelinde uygulanan yasaklara dikkat çekmek adına resmin ortasında genç bir erkek figürü isyan halinde gösterilmiştir (Resim-23). Bu resimlerden de anlaşılacağı üzere gencinden yaşlısına kadar her kesim bu hastalığın (Covid-19) tehdidi altındadır.
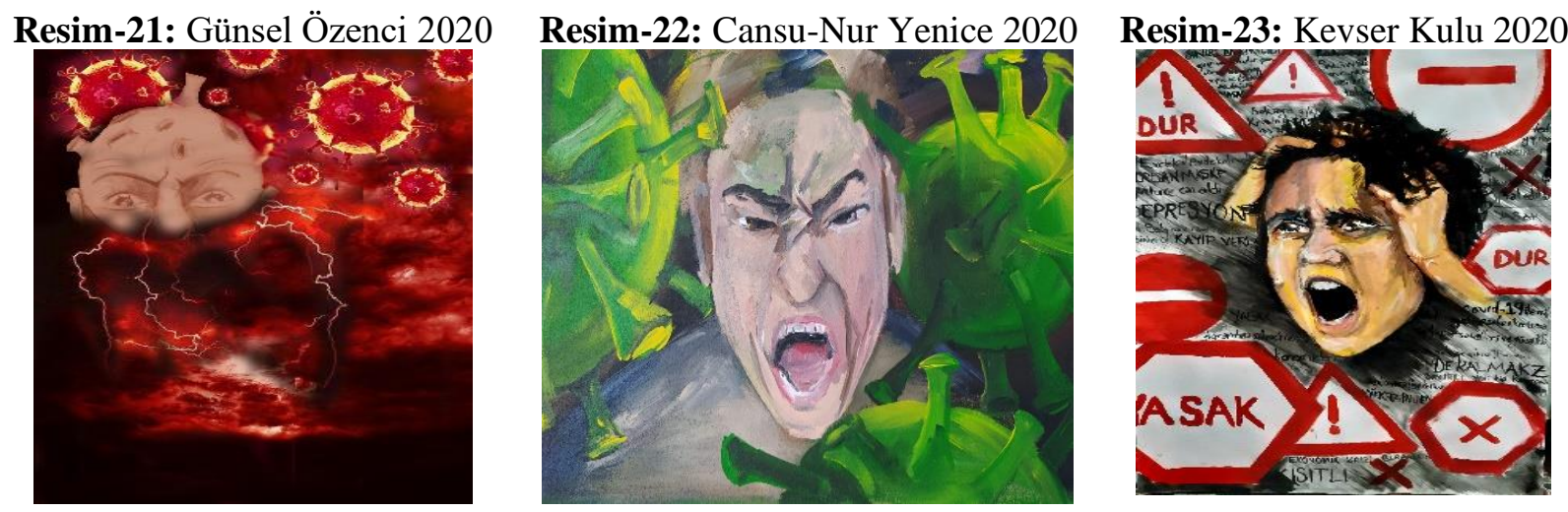
Altta yer alan Resim-24'te ise arka planda Türk bayrağının yer aldığı bir dağ silueti ile ön tarafta koronavirüsle mücadele eden ve birinin eli çaresizliği ifade etmek amaciyla cebinde gösterilen iki sağlık görevlisine yer verilmiştir. Resmin geneli, hastalığın karanlık yüzünü göstermek amacıyla siyah renkle gösterilirken tehlike arz eden virüsler de kırmızı renkle resimde yer almıştır. Türk bayrağının yer aldığı bu dağ, aslında İsviçre Alplerinde ve Avrupa'nın en yüksek zirvelerinden olan Matterhorn Dağı'nın kuzey tarafında "Işık Umuttur" projesi kapsamında yeni tip koronavirüs (Covid-19) salgınıyla mücadeleye destek amacıyla yansıtılmıştır. Ayrıca resimde T.C. Dışişleri Bakanı Mevlüt Çavuşoğlu'nun basına yaptığı açılamada belirttiği Türkiye'den yardım talebinde bulunan ülkelerin 44'üne gönderilen desteklere de vurgu yapılmıştır (https://www.cnnturk.com/dunya/iste-turkiyenin-salgin-boyunca-tibbiyardim-gonderdigi-ulkeler, 2020).

Ortada yer alan resimde ise koronavirüs resmin büyük bir çoğunluğunda yer alırken ağzından virüs salyalarının aktı̆̆ 1 azgın ve tehlikeli bir yaratık olarak resmedilmiştir. Resmin solunda yer alan sağlık çalışanının bu canavar karşısındaki acizliği de elindeki ilaçlı spreyden anlaşılmaktadır (Resim25).

En sağdaki resimde ise hastane ortamında iyileşen bir hastanın taburcu edilmesiyle tüm sağlık ekibinin bu zorlu süreçte elde ettikleri başarının bir göstergesi (moral açısından) olarak hastanın uğurlanma anının resme yansıtılmasıdır. Burada sağlık çalışanları başlarına kutsal hareler konularak taçlandırılmışlardır. Ayrıca kara dağların (sıkıntılı durum) arkasında mavi beyaz bir gökyüzüyle gelecek olan aydınlığa da dikkat çekilmiştir (Resim-26).

Resim-24: Beliz Eroğlu 2020

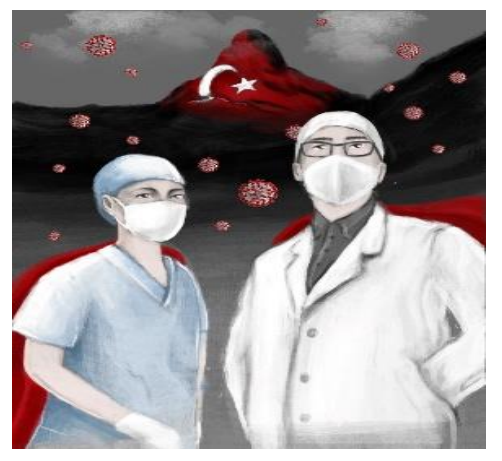

Resim-25: Elif Sude Özbek 2020

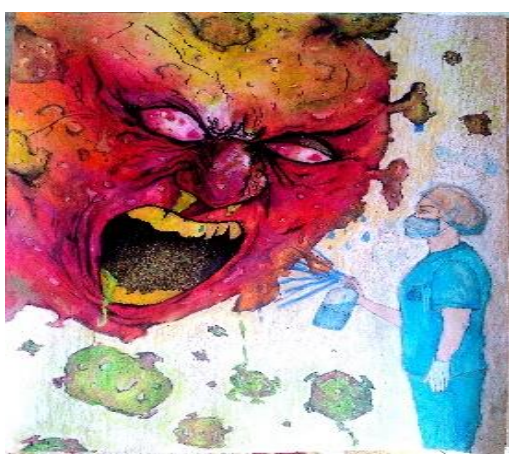

Resim-26: Eda Dönmez 2020

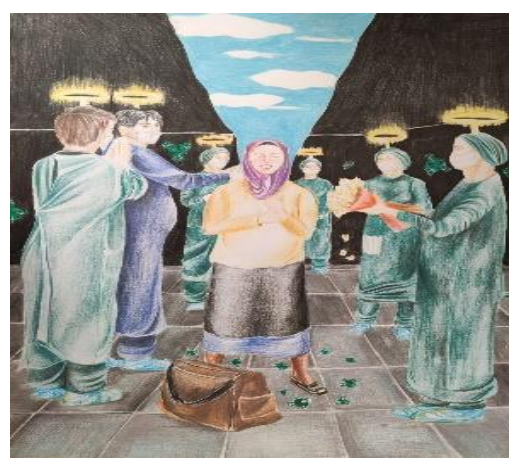

Altta yer alan diğer üç insan figürü (bütün insanları temsilen) haykırışlar içinde ve çaresizlikle bu virüsle mücadele etmektedir. Bu hastalıktaki tehlikeler siyah ve kırmızı ile gösterilirken beyaz renkle umutlar da ihmal edilmemiştir (Resim-27).

Ortadaki resim ise yaşadığımız şu sıkıntılı günlerde insanların toplumsal olarak yaşama haklarından birisi olan evlilik müessesesindeki zorluklara dikkat çekmek için yapılmış bir çalışmadır. Çünkü bu dönemde düğün ve nişan gibi toplumsal olaylarda da bazı yasaklar söz konusu olmuştur (Resim-28).

Son resimde ise ortada yer alan sağlık çalışanı (tüm sağlık çalışanlarını temsilen) elinde koronavirüsü tutarak mücadele etmektedir. Bu virüs şehirlerde, apartmanlarda kısaca her yerde ve her 
evde canları almaya devam etmektedir. Resimde kullanılan siyah ve kırmızılarla bu tehlikelere dikkat çekilmiştir. Ancak bu resimde de ümitler söz konusudur (Resim-29).

Resim-27: Rabia Ak 2020

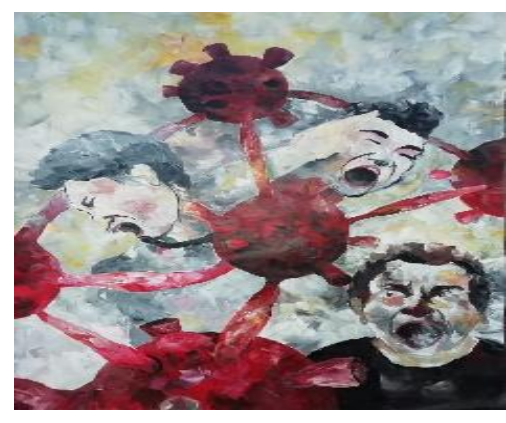

Resim-28: Günseli Özenci 2020

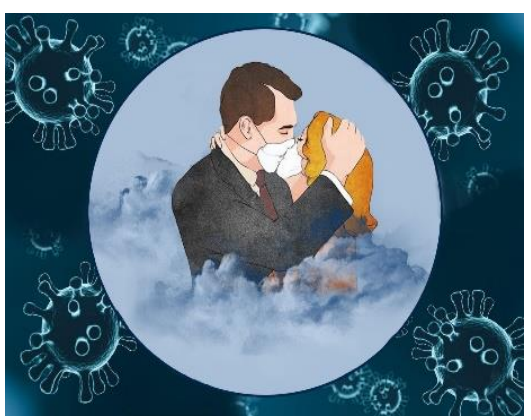

Resim-29: Dilara Yetkin 2020

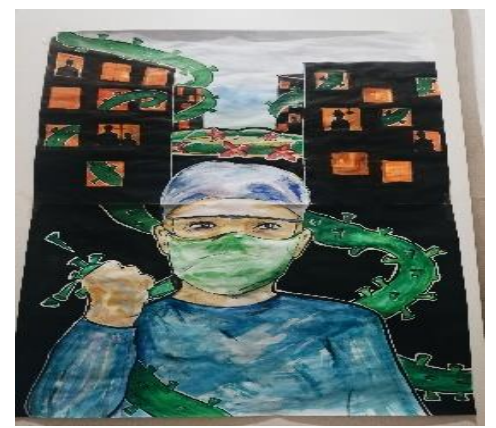

\section{Sonuç}

Sağlıklı toplumlar sağlıklı bireylerden oluşmaktadır. Toplumlardaki bireylerin sağlıklı olabilmeleri ise sağlıkları yanında hastalıklara gerekli hassasiyetleri göstermeleri, sağlıklı davranışlar sergilemeleri ve bireysel davranış özelliklerine bağlı olarak toplumsal düzeyde aile, kültür, sanat, eğitim gibi kurumlarla yakından ilgileriyle mevcuttur. İçinde bulunduğumuz toplumsal yapıyı anlayabilmemiz için ve sözü edilen toplumsal ilişkileri ortaya koyabilmek adına sosyo-kültürel anlamda yapılacak olan çalışmalara ihtiyaç vardır. Aynı zamanda bu alanda yapılacak olan araştırmalara ek olarak toplumun ruh sağlığının korunması da son derece önemli olacaktır.

Sosyo-kültürel olarak tarih sahnelerine baktığımızda sanatçıların eski çağlardaki frengi ve vebadan tüberküloz, kanser, AIDS ve Covid-19'a kadar pek çok hastalığın yarattığı üzüntü, korku, yaşam ve ölüm gibi duyguların aktarımında ana karakter oyuncuları olarak rol aldıkları görülmüştür. Toplumların kolektif hafizalarında derin izler bırakan bu hastalıkların sanat eserlerine aktarımında, travmatik durumların izleyicide yaratacağı çağrışımlar öngörülerek bu olaylar sanatçılar tarafindan ya doğrudan tuvale aktarılmış ya da izleyiciyi travma anına götürerek o duyguyu tekrardan yaşatacak bir anlatım şekli ile sanatçılar tarafından yeniden canlandırılmıştır. Böylece toplumların ruh sağlıkları üzerinde izleri de söz konusu olmuştur.

Bu çalışmada ise Covid-19 örneğinden hareketle, Gazi Üniversitesi Gazi Eğitim Fakültesi Görsel Sanatlar Bölümü Resim Ana Bilim Dalı'ndaki 3. ve 4. sınıf öğrencileri tarafından sosyal ve kültürel açıdan söz konusu hastalık olgusuna ilişkin bilgi, tutum ve davranışlar kendi bakış açıları ile sorgulanmış ve hastalıkla ilgili toplumda yer alan pek çok konuya parmak basılmıştır. Ayrıca, hastalık dolayısıyla kapalı ve açık ortamlarda özgürlükleri bir dönem kısıtlanan söz konusu resim öğrencileri, kızgınlıklarını (Resim-22) ve uygulanan koruma kurallarındaki sınırlılıklarını (Resim-28) gösterirken; konuya yönelik hissiyatlarını da (Resim 20-23-27) isyan eder bir şekilde resmetmişlerdir. Resimlerinde hasta insanların çaresizlikleri ile hastalık karşısındaki panik ve korkularına da (Resim 17-18-21) yer verilmiştir. Örneğin; sağlık çalışanlarının göstermiş oldukları fedakarlıklar ve mücadeleler (Resim 15-16-19-25-29) ile iyileşen hastaların mutlulukları (Resim-26) resimlerinde yer almıştır. Buna ek olarak, ülkemizin dünya genelinde yapmış olduğu yardımların öğrenciler üzerinde olumlu bir etki yarattığı gözlemlenmiştir (Resim 24). Ayrıca, öğrencilerin resimlerinde kullandıklanı mavi, beyaz ve yeşil gibi açık ve temiz renkler de söz konusu hastalığın geçeceğiyle ilgili hissiyatlarını yansıtmıştır. Bu düşüncelerden hareketle 
hazırlanan araştırmanın, ileride konuya ilişskin yapılacak çalışmalara kaynak teşkil etmesi bakımından yararlı olacağı düşünülmektedir.

\section{Kaynakça}

Anter, H. (2019). Sanat yapıtlarında ölüm teması. [Yayınlanmamış Yüksek Lisans Tezi]. Batman Üniversitesi Sosyal Bilimler Enstitüsü.

Aslan, A. (2019). Sanatta travmatik Unsur. Sanat Yazıları, 40: 57-83.

Ayaydın, A. (2020). Psikoloji ve sanat etkileşimi üzerine. Bilim, Eğitim, Sanat ve Teknoloji Dergisi (BEST Dergi), 4(1), 8-12.

Baltaş, Z. (2000). Să̆lık Psikolojisi. Remzi Kitabevi

Erefe, İ., Bayık A., Kocaman, G., Bahar, Z., Aydemir, G.; (1996). Halk Sağlığı Hemşireliği Ders Notları. Ege Üniversitesi Hemşirelik Yüksekokulu.

Fitzpatrick, Ray M. (1991). Society and Changing Patterns of Disease. (Der.) Graham Scambler.

Foster, Hal. (2009). Gerçeğin Geri Dönüşü Yüzyılın Sonunda Avangard. (E. Hoşsucu, Çev.). Ayrıntı Yayınları.

Genç, Ö. (2011). Kara ölüm:1348 Veba Salgını ve Ortaçağ Avrupa'sına Etkileri. Tarih Okulu. Mayıs Ağustos, X, 123-150.

Helman, C. (1984). Culture, Health and Illness. John Wright \& Sons.

Hançerlioğlu, O. (1982). Felsefe Sözlüğü. Remzi Kitabevi.

Kaplan, M. (2016). Kültürel bir insan süreci olarak sağlık: Kavramsal ve Tarihsel bir bakış açısı. Dört Öge. 5, 10, 13.

Kaplanoğlu, L. (2009). Özne nesne ilişkisi bağlamında kübizm, fütürizm ve dada, 23, 188-195 Atatürk Ü. Sosyal Bilimler Enstitüsü Sanat Tarihi Ana Bilim Dalı.

Levinas, E. (2014). Ölüm ve Zaman. (N. Başer, Çev.). Ayrıntı Yayınları.

Nettleton, S. (1995). The Sociology of Health and Illness. Polity Press.

Oskay, Ü. (1993). Medikal Sosyolojide Bazı Kavramsal Açıklamalar. Sosyoloji Dergisi, Ege Üniversitesi Edebiyat Fakültesi Yay., 4, 89-140.

Sarıbaş, S. (2019) “Geçmişten günümüze veba hastalığı 1 ve kolektif bilinç: Çağımızın vebası söyleminin kökenleri. Uluslararası Sosyal ve Beşerî Araştırma Dergisi, 42, 2470-2485.

Schudsom. M. (2007). Toplumsal Hafiza. Muhafazakâr Düşünce Dergisi, 24, 184.

Sontag, S. (2015). Metafor Olarak Hastalık: AIDS ve Metaforları. (O. Akınay, Çev.), Can Sanat Yayınları.

Soygür, H. (1999). Sanat ve "Delilik”. Klinik Psikiyatri Dergisi. 2, 124-133.

Tekin, A. (2007). Sağl1k-Hastalık Olgusu ve Toplumsal Kökenleri Burdur örneği [Yüksek Lisans Tezi]. Süleyman Demirel Ü. Sosyal Bilimler Enstitüsü Sosyoloji Ana Bilim Dalı. 
Tepeyılmaz, S. (2016). Geçmişten bugüne kimlik göstergesi olarak sanat. Uluslararası Sosyal Araştırmalar Dergisi. 9(42/9), 42, 998.

Yüksel, S. Evren. (2016). Travma Anlatıları: Türk Sinemasında Melodram ve Toplumsal Fantezi. Agora Kitaplığ 1

Sarıbaş, S. (2019). Geçmişten Günümüze Veba Hastalığı ve Kolektif Bilinç: "Çağımızın Vebası" Söyleminin Kökenleri. Journal of Social and Humanities Sciences Research, 6(42), 2470-2485.

https://www.cnnturk.com/dunya/iste-turkiyenin-salgin-boyunca-tibbi-yardim-gonderdigi-ulkeler

https://www.worldometers.info/coronavirus/

\section{Görsel Kaynakça (Çevrimiçi)}

(Resim-1)

https://www.britishmuseum.org/collection/object/W_1883-0118-AH-2598 Alınan Tarih: 23.06.2020

$(\operatorname{Resim}-2)$

https://www.lwl.org/uruk/start_html/html/3xx/uruk-ausstellung/die-ausstellung/mythos-lang=en.html Alınan Tarih: 23.06.2020

(Resim-3-4-5)

http://www.dodedans.com/Eparis-1486.htm Alınan Tarih: 23.06.2020

$(\operatorname{Resim}-4)$

https://www.nybooks.com/daily/2017/01/20/even-the-emperor-holbein-dance-of-death/ Alınan Tarih: 23.06.2020

(Resim-5)

https://www.tumblr.com/search/johann\%20elias\%20ridinger Alınan Tarih: 23.06.2020

(Resim-6)

https://tr.wikipedia.org/wiki/\%C3\%961\%C3\%BCm\%C3\%BCn_Zaferi Alınan Tarih: 20.05.2020

(Resim-7)

https://www.pivada.com/pablo-picasso-avignonlu-kizlar Alınan Tarih: 20.05.2020

(Resim-8)

https://www.edvardmunch.org/images/gallery/The-Dead-Mother-and-the-Child-1897.jpg Alınan Tarih:

Alınan Tarih: 20.05.2020

(Resim-9)

https://www.edvardmunch.org/the-scream.jsp Alınan Tarih: 23.06.2020

(Resim-10)

https://www.edvardmunch.org/evening-on-karl-johan-street.jsp Alınan Tarih: 20.05.2020

Turkish Studies, 15(4) 
Bir Salgın Hastalık Olarak Covid-19’un Gazi Üniversitesi Gazi Eğitim Fakültesi Güzel Sanatlar...1313 (Resim-11)

https://www.wikiart.org/en/edvard-munch/golgotha-1900 Alınan Tarih: 23.06.2020

(Resim-12)

https://www.renemagritte.org/the-collective-invention.jsp Alınan Tarih: 20.05.2020

(Resim-13)

https://www.ressamlar.gen.tr/gustav-klimt/olum-ve-yasam/ Alınan Tarih: 20.05.2020

(Resim-14)

http://wiki.pinsify.xyz/index.php?q=aHR0cHM6Ly91bi53aWtpcGVkaWEub3JnL3dpa2kvVGhlX1Ns YXZ1X1NoaXA Alınan Tarih: 23.06.2020 